\title{
New perspectives on molecular targeted therapy in ovarian clear cell carcinoma
}

\author{
D S P Tan ${ }^{1,3}$, R E Miller ${ }^{1,2,3}$ and S B Kaye ${ }^{*, 1}$ \\ ${ }^{1}$ Cancer Research UK, Professor of Medical Oncology, Drug Development Unit, Royal Marsden NHS Foundation Trust, Section of \\ Medicine, The Institute of Cancer Research, Sycamore House, Downs Road, Sutton SM2 5PT, UK and ${ }^{2}$ The Breakthrough Breast \\ Cancer Research Centre, Institute of Cancer Research, London, UK
}

Ovarian clear cell carcinomas (OCCCs) account for about 5-13\% of all epithelial ovarian carcinomas in Western populations. It is characterised by resistance to conventional platinum-based chemotherapy, and new therapeutic strategies are urgently required. This article will focus on how recent discoveries have enhanced our understanding of the molecular pathogenesis of OCCCs, leading to new therapeutic opportunities. These include mutations in ARID1A, which provides a link to endometriosis, upregulation of the phosphatidylinositol 3-kinase/AKT pathway, particularly through mutations of PIK3CA and inactivation of PTEN, and increased activity of pathways involved in angiogenesis. Targeting HER2, apoptotic escape mechanisms and mismatch repair defects offer additional opportunities for treating this enigmatic tumour subtype.

There is now compelling evidence to suggest that epithelial ovarian cancers (EOCs) represent a heterogeneous group of tumours with distinct subtypes having different tissues of origin, molecular characteristics and outcome (Kurman and Shih, 2010). In Western populations, ovarian clear cell carcinomas (OCCCs) account for about $5-13 \%$ of all EOCs (Chan et al, 2008; McCluggage, 2008), whereas in Japan, its prevalence rises to $15-25 \%$ (Sugiyama et al, 2000; Itamochi et al, 2008) of all EOCs. It is currently unclear why OCCCs are more common in women of oriental descent, but, regardless of ethnicity, OCCCs have been shown to be associated with a poorer prognosis and are relatively resistant to conventional platinum-based chemotherapy when compared with other EOC subtypes (Tan and Kaye, 2007).

In a large retrospective analysis of 1411 (795 Stage I, 47 Stage II, 295 Stage III, 166 Stage IV) cases of OCCCs (Chan et al, 2008), OCCCs were associated with a poorer prognosis across all stages compared with other EOC subtypes. Interestingly, there are also data from smaller studies suggesting that early-stage OCCCs may actually have an equivalent or better prognosis than early-stage serous EOC (Kennedy et al, 1989; Köbel et al, 2010). However, in the setting of advanced disease, studies have consistently demonstrated a significantly poorer prognosis in advanced OCCC when compared with serous EOC (Chan et al, 2008; Mackay et al, 2010). Furthermore, in patients with platinum-sensitive or -resistant (i.e., $>6$ months or $<6$ months of platinum-free interval, respectively) relapsed OCCCs, reported response rates to second line chemotherapy are only between 0 and $8 \%$ (Pather and Quinn, 2005; Takano et al, 2008). Consequently, OCCCs present a considerable clinical challenge and there is a need to optimise currently available treatments and develop new therapeutic strategies in the management of this disease.

Increasingly, a greater understanding of the molecular pathogenesis and heterogeneity of cancer has led to the development of more effective treatment strategies in various tumour types. In this article, the recent advances in our understanding of the molecular characteristics and pathogenesis of OCCCs and how they may facilitate the development of targeted therapeutic strategies in this enigmatic EOC subtype are reviewed.

\section{OVARIAN CLEAR CELL CARCINOMA IS A} HETEROGENEOUS DISEASE

From a histopathological perspective, OCCCs have conventionally been considered a uniform entity and are usually classified as highgrade carcinomas (McCluggage, 2008). Early gene expression analyses (Schwartz et al, 2002; Zorn et al, 2005) of OCCCs also suggested that they appear to represent a distinct and possibly homogenous subtype of EOCs at the molecular level (Zorn et al, 2005).

\footnotetext{
*Correspondence: Professor SB Kaye; E-mail: stan.kaye@rmh.nhs.uk

${ }^{3}$ These two authors contributed equally to this work.
} 
Evidence for the molecular genetic and phenotypic heterogeneity of OCCCs can be seen, however, in early conventional comparative genomic hybridisation studies of these tumours, where distinct DNA copy number abnormalities were observed in subsets of OCCCs (Suehiro et al, 2000) and specific copy number gains could be correlated with overall survival (Hirasawa et al, 2003). In a study by Tan et al (2011), 50 archival OCCCs were subjected to high-resolution microarray-based comparative genomic hybridisation analysis to determine whether distinct genomic subgroups of OCCCs existed. The study revealed that OCCCs are genetically heterogeneous (Tan et al, 2011) and can be further subdivided into distinct patterns of copy number aberration. Moreover, by performing unsupervised hierarchical clustering analysis based on the genomic copy aberrations, two distinct genomic subgroups of OCCCs (cluster-1 and cluster-2) that did not significantly differ in terms of their clinicopathological and histological features were identified. Subsequent survival analysis revealed that patients from cluster- 1 had a significantly shorter median progression-free survival (PFS) than those from cluster-2 (11 vs 65 months, $P=0.009$ ) and subsequent multivariate analysis revealed that genomic cluster was an independent prognostic factor for PFS.

These data suggest that OCCCs are genomically heterogeneous and that the pattern and complexity of genome-wide copy number aberrations are not only of taxonomic interest, but may also underpin the phenotypic differences in OCCCs with regard to clinical outcome. Indeed, it would appear that subgroups of OCCCs may harbour specific copy number changes that render them more chemoresistant than other OCCCs (Tan et al, 2011). This heterogeneity has now been extended to include patterns of gene mutations and aberrations in signalling pathways that have emerged on the molecular landscape of OCCCs in recent years (Anglesio et al, 2011a) and are now providing us with a framework (Table 1) for the development of targeted therapeutic approaches.

TARGETING THE EMERGING MOLECULAR LANDSCAPE OF OCCC

ARID1A mutations in OCCCs: therapeutic implications. Unlike serous EOC, which is thought to originate in the distal fallopian tube (Lee et al, 2007), the association of OCCCs with endometriosis up to $58 \%$ of cases (Jenison et al, 1989) and the identification of similar somatic mutations found in both OCCCs and adjacent atypical endometriosis (Wiegand et al, 2010) has led to the suggestion that OCCCs do not originate from the ovarian epithelium, but represent transformed neoplastic cells from displaced endometriotic tissue (Anglesio et al, 2011a). Recent studies have identified putative driver genes and aberrant pathways present in endometriotic lesions that may be essential for malignant transformation and the development of OCCC (Wiegand et al, 2010; Yamamoto et al, 2011). Endometriotic cysts have also been found to contain a high concentration of free iron that may promote carcinogenesis by iron-induced persistent oxidative stress (Yamaguchi et al, 2008) and induction of an 'OCCC genomic signature' has been reported in immortalised ovarian surface epithelial cells when exposed to the contents of endometriotic cysts (Yamaguchi et al, 2010). Hence, early differentiation into the clear cell lineage may take place in ovarian endometriosis, with subsequent carcinogenesis being influenced by the microenvironment of the endometriotic cysts, thus leading to its frequent association with OCCC.

Wiegand et al (2010) identified somatic mutations in ARID1A (the AT-rich interactive domain 1A (SWI-like) gene, which encodes BAF250a, a key component of the SWI-SNF chromatin remodelling complex) in $46 \%$ of OCCCs (55 out of 119) and found mutation status was associated with loss of ARID1A (BAF250a) protein expression. ARID1A mutations and loss of protein expression were also evident in contiguous atypical endometriosis associated with two OCCCs harbouring mutations (Wiegand et al, 2010). Subsequent studies have confirmed ARID1A mutations in $57 \%$ of primary OCCCs using exome sequencing (Jones et al, 2010). Loss of ARID1A expression has been correlated with shorter PFS and overall survival in patients with OCCCs following platinum-based chemotherapy (Katagiri et al, 2011).

ARID1A is a component of the SWI/SNF chromatinremodelling complex, which alters chromatin structure by ATPdependent disruption of histone-DNA interaction (Reisman et al, 2009). The complex has a major role in the repair of DNA lesions directly by facilitating DNA accessibility on the chromatin or indirectly by facilitating the functions of DNA repair proteins, such as p53, BRCA1, GADD45 and Fanconi Anemia proteins (Reisman et al, 2009). By altering the accessibility of chromatin, it also regulates many cellular processes, including development, differentiation and proliferation (Nagl et al, 2005; Gao et al, 2008; Reisman et al, 2009). The SWI/SNF complex is increasingly being recognised as a bona fida tumour-suppressor complex with mutations in a number of subunits identified in a variety of malignancies (Gui et al, 2011; Wilson and Roberts, 2011; Mamo et al, 2012; Shain et al, 2012). The exact mechanisms by which mutations in this complex-drive tumourigenesis are unclear. However, ARID1A has recently been demonstrated, albeit in a small number of models, to act as a negative regulator of the cell cycle through interaction with p53 (Guan et al, 2011). Ovarian clear cell carcinomas with mutations in the ARID1A subunit frequently lack genomic instability (Wiegand et al, 2010) and it has been suggested that perturbations in the regulation of chromatin remodelling may be able to substitute for genomic instability in OCCC tumourigenesis (Wilson and Roberts, 2011). The multifaceted role of the SWI/SNF complex provides a tantalising hint to the potential utility of targeted approaches in signalling pathways that are transcriptionally dysregulated by loss of SWI/SNF function (Wilson and Roberts, 2011). These include downregulation of cyclin-dependent kinase inhibitor p16 ${ }^{\mathrm{INK} 4 \mathrm{~A}}$ expression (Wilson and Roberts, 2011), overexpression of the polycomb group protein $\mathrm{EZH} 2$, which has been implicated in the pathogenesis of ovarian and renal carcinomas (Wilson and Roberts, 2011), increased expression of the oncogenic proteins cyclin D1 and MYC (Wilson and Roberts, 2011), aberrant activation of the Hedgehog signalling pathway (Wilson and Roberts, 2011) and aberrant regulation of pro-motility proteins involved in invasion and metastasis such as increased activity of the Ras homolog gene family member A GTPase and RHO-associated protein kinase 1 which regulate the actin cytoskeleton and promote cell migration (Wilson and Roberts, 2011). It can therefore be envisaged that once the constitutional defects of the cellular functions caused by ARID1A mutation in OCCCs are accurately catalogued, they can be explored for the development of novel targeted therapies.

Targeting the phosphatidylinositol 3-kinase (PI3K)/Akt/ mammalian target of rapamycin (mTOR) pathway. The PI3K pathway is thought to have an important role in the pathogenesis of OCCC (Kuo et al, 2009). Mutations of PIK3CA (which encodes p1 $10 \alpha$, the catalytic subunit) have been identified in 33\% of OCCC patients (Kuo et al, 2009) and are present in the endometriosis of patients with OCCC harbouring PIK3CA mutations (Yamamoto et al, 2011). A broad range of functions related to cancer progression are associated with PI3K activity, including proliferation, cell adhesion, apoptosis and transformation (Engelman, 2009). It has been shown that PI3K regulates G1 cell cycle progression and cyclin expression through activation of Akt/ mTOR/p70S6K1 signalling pathway in ovarian cancer cells (Engelman, 2009) and promotes cell survival through a variety of 
Table 1. Molecular characteristics of ovarian clear cell carcinomas and their cellular effectsAbbreviations: ARID1A=AT-rich interactive domain 1A; $\mathrm{ATM}=$ ataxia-telangiectasia mutated; $\mathrm{MSI}=$ microsatellite instability; $\mathrm{mTOR}=$ mammalian target of rapamycin; PI3K = phosphatidylinositol 3-kinase; PPP2R1A = protein phosphatase 2 regulatory subunit $A$.

\begin{tabular}{|c|c|c|}
\hline Molecular characteristic & Frequency & Cellular effect \\
\hline ARID1A mutation (Jones et al, 2010; Wiegand et al, 2010) & $40-57 \%$ & $\begin{array}{l}\text { - Loss of BAF250a, a key component of the SWI-SNF } \\
\text { chromatin remodelling complex }\end{array}$ \\
\hline IL6-STAT3-HIF upregulation (Anglesio et al, 2011b) & IL-6 expression in $49 \%$ & - Angiogenesis \\
\hline HNF-1 $\beta$ upregulation (Kato et al, 2006; Yamaguchi et al, 2010) & Almost $100 \%$ & - Apoptotic escape \\
\hline TMS/1/ASC methylation (Terasawa et al, 2004) & $69 \%$ & - Apoptotic escape \\
\hline $\begin{array}{l}\text { PI3K/AKT/mTOR pathway activation by PTEN loss (Hashiguchi et al, } \\
\text { 2006)/PIK3CA mutation (Kuo et al, 2009)/AKT2 amplification (Tan } \\
\text { et al, 2011) }\end{array}$ & $\begin{array}{l}\text { PTEN loss in } 40 \% \\
\text { PIK3CA mutation in } 33 \% \\
\text { AKT2 amplification } 14 \%\end{array}$ & $\begin{array}{l}\text { - Activation of cell cycle progression } \\
\text { - Inhibition of apoptosis } \\
\text { - Increased cell motility } \\
\text { - Impaired homologous recombination }\end{array}$ \\
\hline HER2 amplification and overexpression (Tan et al, 2011) & $14 \%$ & $\begin{array}{l}\text { - Activation of PI3K, MAPK, STAT signalling pathways } \\
\text { - Promotes cellular proliferation } \\
\text { - Inhibition of apoptosis }\end{array}$ \\
\hline PPM1D amplification (Tan et al, 2009) & $10 \%$ & - Negative regulation of p53, Chk2 and ATM \\
\hline $\begin{array}{l}\text { Loss of mismatch repair genes (hMLH1 and hMSH2; Cai et al, 2004; } \\
\text { Pal et al, 2008; Ketabi et al, 2011) }\end{array}$ & $7-18 \%$ & - MSI \\
\hline PPP2R1A mutations (Jones et al, 2010) & $7 \%$ & Impaired PP2A function leading to uncontrolled cell growth \\
\hline KRAS mutations (Jones et al, 2010) & $4.7 \%$ & $\begin{array}{l}\text { Activation of RAS/RAF/MEK/ERK and PI3K/AKT/mTOR } \\
\text { pathways }\end{array}$ \\
\hline
\end{tabular}

mechanisms, including phosphorylation and inactivation of proapoptotic proteins Bad and caspase-9 (Khwaja, 1999; Neve et al, 2006).

Loss of PTEN expression, which is a key negative regulator of the PI3K pathway has been noted in $40 \%$ of early-stage OCCC, suggesting that PTEN inactivation may be an early event in OCCC development (Hashiguchi et al, 2006). In another study, Mabuchi et al (2009) performed immunohistochemical (IHC) analysis of phospho-mTOR expression in a tissue microarray of 98 primary ovarian cancers and showed that mTOR was more frequently activated in OCCC than in serous carcinomas (86.6\% vs 50\%). AKT2 amplification has also recently been described in a subgroup of OCCCs that are associated with a shorter PFS (Tan et al, 2011).

Given that the PI3K/AKT/mTOR signalling pathway is more frequently activated in OCCCs (Mabuchi et al, 2009), it would appear a potential therapeutic pathway that can be utilised for a targeted approach to treatment. Mabuchi et al (2009) recently showed that cell growth was markedly inhibited in both cisplatin-sensitive parental and cisplatin-resistant human OCCC cell lines following treatment with the mTOR inhibitor everolimus, and a variety of additional candidate compounds targeting this pathway,for example, the AKT inhibitor MK2206 (Yap et al, 2011), are now available. The majority of the agents targeting the PI3K pathway are in early-phase clinical trials and, to date, there is no evidence that support their use in the management of OCCCs, furthermore, there is a move towards combination strategies to improve efficacy. A single-arm phase II study is currently underway examining the combination of the mTOR inhibitor temsirolimus with carboplatin and paclitaxel for the first-line treatment of patients with advanced OCCC (http://clinicaltrials.gov/ct2/show/NCT01196429).
Recent evidence also suggests that PTEN is involved in the maintenance of genomic stability and that loss of PTEN function results in defective homologous recombination-mediated repair of DNA double-strand breaks, thus sensitising cells to inhibition of the poly (adenosine diphosphate ribose) polymerase (Dedes et al, 2010). Hence, PTEN-deficient OCCCs may also be sensitive to poly(adenosine diphosphate ribose) polymerase inhibitors like olaparib (Dedes et al, 2010).

Targeting angiogenesis in OCCCs. Vascular endothelial growth factor (VEGF) has several known activities pertinent to tumour growth and progression (Campos and Ghosh, 2010). In ovarian cancer, increased levels of VEGF have been associated with a poorer prognosis and platinum resistance in EOCs (Siddiqui et al, 2011). Recent randomised phase III trials involving the combination of chemotherapy with the anti-VEGF agent bevacizumab in both the adjuvant and relapsed settings of EOC demonstrated improved response rates and prolonged PFS with the addition of bevacizumab, although response rates in specific histological subgroups were not examined (Heitz et al, 2012).

Mabuchi et al (2010) demonstrated that VEGF was strongly expressed both in early- and advanced-stage OCCCs, and that early-stage OCCCs with high levels of VEGF had significantly shorter survival than those with lower levels of VEGF expression. Furthermore, expression of VEGF in vitro was found to be significantly higher in cisplatin-refractory human OCCC cells when compared with the cisplatin-sensitive parental cells (Mabuchi et al, 2010). Recently, Anglesio et al (2011b) demonstrated specific overexpression of the pro-angiogenic IL6-STAT3-HIF (interleukin-6 signal transducer and activator of transcription-3 hypoxiainduced factor) pathway in OCCC tumours compared with 
high-grade serous cancers and reported sustained clinical and functional imaging responses in two patients with chemotherapyresistant OCCCs who were treated with sunitinib, a multi-targeted receptor tyrosine kinase inhibitor, which inhibits both plateletderived growth factor receptor and the VEGF receptor. A National Cancer Institute of Canada funded phase II study (NCT01396408) investigating the efficacy of sunitinib in patients with advanced rare tumours, including recurrent OCCC, is currently ongoing (http://clinicaltrials.gov/ct2/show/NCT01396408). Similarly, increased activity of pathways involved in angiogenesis and hypoxic cell growth has been observed after whole-gene expression profiling of microdissected OCCCs, as well as marked inhibition of OCCC cell growth in vitro and in vivo following inhibition of HIF1- $\alpha$ and treatment with sunitinib (Stany et al, 2011). It remains to be seen, however, if the efficacy of anti-angiogenic therapy applies to all EOC subtypes or is particularly enhanced when used in patients with OCCCs.

HER2 as a therapeutic target in OCCCs. Amplification and overexpression of HER2 have been described in 14\% of OCCCs (Tan et al, 2011). In a study by Schwartz et al (2002), a molecular signature that distinguished OCCC from other histological types of EOC identified a total of 73 genes with greater than two-fold higher expression in OCCC, including HER2 (Schwartz et al, 2002). In addition, Trastuzumab, a humanised recombinant monoclonal antibody, against HER2 significantly and dosedependently reduces the growth of the HER2-overexpressing OCCC cell line RMG-1 in vitro and in vivo and prolonged the survival of RMG-1 xenografted mice (Fujimura et al, 2002). Hence, there are data to suggest that HER2 may be an additional therapeutic target in OCCCs. In a previous phase II study of trastuzumab monotherapy in recurrent EOC (with HER2 overexpression documented by IHC), an overall response rate of only $7 \%$ was observed (Bookman et al, 2003). However, patient selection (41 patients of which 7 were OCCCs) was only based on HER2 IHC expression levels without assessment of HER2 copy number status (Bookman et al, 2003). Future studies designed to assess the predictive value of HER2 amplification and overexpression and response to trastuzumab or other anti-HER2 agents in OCCCs are warranted.

Targeting apoptotic escape mechanisms in OCCC. Mutations in p53 are a common event in tumourigenesis, being particularly common in serous ovarian carcinomas ( $\sim 96 \%$; Hetland et al, 2011), but are remarkably uncommon in OCCC (9-10\%; Tan and Kaye, 2007). This implies that other antiapoptotic mechanisms are likely to be involved in the development of OCCC. HNF-1 $\beta$, an IHC marker for OCCCs (Kobel et al, 2009), has been implicated in mediating apoptotic escape in tumour cells and is upregulated and overexpressed in OCCC cell lines (Yamaguchi et al, 2010). Kato et al (2006) examined 30 OCCCs and found nuclear expression of HNF-1 $\beta$ in all OCCC tumours, whereas it was rarely expressed in other EOC subtypes. In addition, distinct nuclear immunostaining for HNF-1 $\beta$ was detected in endometriotic epithelia associated with OCCCs (Kato et al, 2006). Furthermore, $40 \%$ of endometriotic cysts without neoplastic changes also expressed HNF-1 $\beta$, mainly in areas exhibiting inflammatory atypia (Kato et al, 2006). This indicates a mechanism for apoptotic escape in early OCCC tumour development, which may also have implications for drug resistance. Aberrant methylation resulting in transcriptional silencing of TMS1/ASC, a member of the caspase recruitment domain family of proapoptotic mediators, has also been frequently observed in OCCC tumours (Terasawa et al, 2004).

PPM1D (protein phosphatase magnesium-dependent 1 delta) encodes for a protein phosphatase with established oncogenic functions (Lu et al, 2008) that has been shown to negatively regulate the TP53 (Takekawa et al, 2000), Chk2 (Fujimoto et al, 2006) and ataxia-telangiectasia-mutated (ATM) kinase (Shreeram et al, 2006), tumour-suppressor proteins. Amplification and overexpression of the PPM1D are present in $\sim 10 \%$ of OCCCs (Tan et al, 2009) and have been associated with a poorer outcome (Hirasawa et al, 2003). Inhibition of PPM1D in PPM1D-amplified OCCC cells results in reduced cell survival, suggesting this is a potential therapeutic target for a subset of OCCCs (Tan et al, 2009). The anti-apoptotic function of PPM1D may be particularly pertinent in driving the biology of tumours with wild-type TP53 and the relevance of this hypothesis to OCCC is given further credence by the low prevalence of TP53 mutations in OCCCs (Tan et al, 2009).

Reduced expression of the apoptotic activator BAX has been noted in patients with chemoresistant EOC (Spentzos et al, 2005), whereas high levels of BAX have been correlated with sensitivity to paclitaxel and improved survival in patients with EOC (Courjal et al, 1997). Among the IHC characteristics of OCCC is the notable overexpression of the proapoptotic protein BAX in stage I and II OCCC tumours (Skirnisdottir et al, 2005). In addition, the antiapoptotic protein $\mathrm{Bcl}-2$, which inhibits BAX-mediated apoptosis, has been observed to be more highly expressed in metastatic deposits than primary OCCCs (Yoshida et al, 2001). A p53mediated pathway has been implicated in the induction of cell death following DNA damage by platinum-based chemotherapeutic agents, which results in a decrease in the relative ratio of Bcl-2/ BAX, thus favouring apoptosis (Sheikh-Hamad et al, 2004). Hence, the presence of a lower relative ratio of $\mathrm{Bcl}-2 / \mathrm{BAX}$ in early-stage OCCC tumours, and a higher relative ratio of $\mathrm{Bcl}-2 / \mathrm{BAX}$ in metastatic OCCC lesions, may account for the reported dichotomy in outcome observed in good prognosis early-stage OCCC tumours $v s$ the relatively more platinum-resistant and poorer prognosis latestage OCCC tumours. In this context, the potent, orally bioavailable Bcl-2 family inhibitor ABT-263 (Navitoclax) may be of potential interest in patients with high levels of Bcl-2 expression (Gandhi et al, 2011). Notably, in vitro data suggest that ovarian cell lines that express Bcl-2 family proteins exhibit strong synergy in terms of growth inhibition when navitoclax is combined with paclitaxel (Wong et al, 2012).

Targeting mismatch repair (MMR) defects in OCCCs. Microsatellite instability (MSI), caused by defects in the DNA MMR genes, has been observed at high levels (i.e., MSI-high) and low levels (i.e., MSI-low) in 14\% and 7\% of OCCCs, respectively, with a strong correlation between alterations in the expression of hMLH1 and hMSH2 and the presence of MSI in these tumours (Cai et al, 2004). Further evidence that a subset of OCCCs are associated with MMR defects was observed in a study of Swedish and Danish Lynch syndrome ovarian cancer patients of which $17 \%$ had OCCCs (Ketabi et al, 2011). A meta-analysis of various histological subtypes of MMR-deficient EOC has also reported that OCCCs represent about $18 \%$ of these tumours ( $\mathrm{Pal}$ et al, 2008). The therapeutic relevance of MMR deficiency has recently been elucidated in a study demonstrating that methotrexate induces oxidative DNA damage and is selectively lethal to tumour cells with MMR defects via inhibition of dihydrofolate reductase (Martin et al, 2009).

Protein phosphatase 2 regulatory subunit A (PPP2R1A) and KRAS mutations. Presumed oncogenic mutations in $P P P 2 R 1 A$, which encodes a constant regulatory subunit of the serine/ threonine protein phosphatase $\mathrm{PP} 2 \mathrm{~A}$ that is involved in the control of cell growth and division, have been reported in $7 \%$ of OCCCs (Jones et al, 2010). Although its role in the pathogenesis of OCCCs is unclear, impaired PP2A activity has also been observed in haematological malignancies and is a potentially druggable target (Perrotti and Neviani, 2008). Mutations of KRAS have also been reported in $4.7 \%$ of OCCCs (Jones et al, 2010), which suggests that therapeutic strategies using drugs that inhibit signal transduction downstream of RAS (Dienstmann et al, 2012), such 
as MEK and PI3K/AKT/mTOR inhibitors, may be worth exploring in this subset of OCCCs as well.

\section{EXPERIMENTAL MODELS OF OCCCS}

In order to further understand OCCCs and develop novel therapeutics, appropriate preclinical models are required. Human cancer cell lines and xenograft models are traditionally used for the identification of molecular aberrations and drug sensitivities. Although relatively few OCCC cell lines exist compared with other EOC subtypes, they appear to reflect the mutational pattern seen in patients with $50 \%$ of cell lines harbouring ARID1A mutations (4 out of 8 ) and one-third with PIK3CA (3 out of 9) mutations, as well as lower frequencies of KRAS (1 out of 9) and BRAF (1 out of 9) mutations, and PPM1D amplification (1 out of 12; Tan et al, 2009; Guan et al, 2011; Rahman et al, 2012). Xenografts of human cancer cell lines into immunodeficient mice are used to examine the efficacy of therapeutic compounds and the tumourogenicity of cells, and OCCC xenografts have been successful using subcutaneous, intraperitoneal and orthotopic transplantation (Shaw et al, 2004). To our knowledge animal models in which de novo OCCC develop do not exist. However, patient-derived human xenografts are increasingly being used for oncology drug development (Tentler et al, 2012) and OCCC tumours have been successfully established to mimic patient tumour biology and heterogenetity (Dobbin et al, 2012). It is essential that as we gain an increased understanding of the molecular landscape of OCCCs, appropiate models are developed alongside to assist with the development of novel therapeutic approaches.

\section{FUTURE PERSPECTIVES AND CONCLUSION}

In recent years, it has also become increasingly clear that unlike high-grade serous ovarian cancer, which is characterised by TP53 mutations (Ahmed et al, 2010) and frequent mutations or defects in BRCA1 or BRCA2 pathway (Gross et al, 2010; Kurman and Shih, 2010), OCCCs appear to harbour a different pattern of molecular events such as activating mutations in PIK3CA and loss of PTEN (Tan and Kaye, 2007) and ARID1A (Wiegand et al, 2010). The precursor lesion for OCCC remains unknown but current evidence suggests that a proportion of OCCCs may have developed from endometriotic precursor lesions (Wiegand et al, 2010). The distinct molecular features of OCCC and serous ovarian cancer serve to emphasise the need to develop subtype-specific therapeutic approaches in the management of EOC. Furthermore, despite displaying histologically uniform features, OCCCs do not constitute a single entity and may be classified into distinct molecular genetic subtypes that also appear to be associated with clinical outcome (Tan et al, 2011). Additionally, a question which remains unanswered is whether OCCCs observed in Asian and Western populations are molecularly distinct entities, which might require different therapeutic approaches.

It is envisaged that further elucidation of the underlying genetic mechanisms driving the development of OCCCs will provide a foundation for future studies exploring novel therapeutic approaches. Currently, there is insufficient evidence to recommend specific treatment for patients with OCCC, although we believe they are best treated in centres with OCCC-specific trials. Ultimately, it is our hope that these studies will eventually enable clinicians to offer an individualised treatment plan for patients with OCCC that will allow for differences in behaviour and therapeutic responses to be addressed early, rather than a 'one size fits all' treatment approach, thus fulfilling the promise of personalised medicine.

\section{REFERENCES}

Ahmed AA, Etemadmoghadam D, Temple J, Lynch AG, Riad M, Sharma R, Stewart C, Fereday S, Caldas c, Defazio A, Botwell D, Brenton JD (2010) Driver mutations in TP53 are ubiquitous in high grade serous carcinoma of the ovary. J Pathol 221(1): 49-56.

Anglesio MS, Carey MS, Kobel M, Mackay H, Huntsman DG (2011a) Clear cell carcinoma of the ovary: a report from the first Ovarian Clear Cell Symposium, June 24th, 2010. Gynecol Oncol 121(2): 407-415.

Anglesio MS, George J, Kulbe H, Friedlander M, Rischin D, Lemech C, Power J, Coward J, Cowin PA, House CM, Chakravarty P, Gorringe KL, Campbell IG. Australian Ovarian Cancer Study GroupOkamoto A, Birrer MJ, Huntsman DG, de Fazio A, Kalloger SE, Balkwill F, Gilks CB, Bowtell DD (2011b) IL6-STAT3-HIF signaling and therapeutic response to the angiogenesis inhibitor sunitinib in ovarian clear cell cancer. Clin Cancer Res 17(8): 2538-2548.

Bookman MA, Darcy KM, Clarke-Pearson D, Boothby RA, Horowitz IR (2003) Evaluation of monoclonal humanized anti-HER2 antibody, trastuzumab, in patients with recurrent or refractory ovarian or primary peritoneal carcinoma with overexpression of HER2: a phase II trial of the Gynecologic Oncology Group. J Clin Oncol 21(2): 283-290.

Cai KQ, Albarracin C, Rosen D, Zhong R, Zheng W, Luthra R, Broaddus R, Liu J (2004) Microsatellite instability and alteration of the expression of hMLH1 and hMSH2 in ovarian clear cell carcinoma. Hum Pathol 35(5): 552-559.

Campos SM, Ghosh S (2010) A current review of targeted therapeutics for ovarian cancer. J Oncol 2010: 149362.

Chan JK, Teoh D, Hu JM, Shin JY, Osann K, Kapp DS (2008) Do clear cell ovarian carcinomas have poorer prognosis compared to other epithelial cell types? A study of 1411 clear cell ovarian cancers. Gynecol Oncol 109(3): 370-376.

Courjal F, Cuny M, Simony-Lafontaine J, Louason G, Speiser P, Zeillinger R, Rodriguez C, Theillet C (1997) Mapping of DNA amplifications at 15 chromosomal localizations in 1875 breast tumors: definition of phenotypic groups. Cancer Res 57(19): 4360-4367.

Dedes KJ, Wetterskog D, Mendes-Pereira AM, Natrajan R, Lambros MB, Geyer FC, Vatcheva R, Savage K, Mackay A, Lord CJ, Ashworth A, ReisFilho JSl (2010) PTEN deficiency in endometrioid endometrial adenocarcinomas predicts sensitivity to PARP inhibitors. Sci Transl Med 2(53): 53 ra75.

Dienstmann R, De Dosso S, Felip E, Tabernero J (2012) Drug development to overcome resistance to EGFR inhibitors in lung and colorectal cancer. Mol Oncol 6(1): 15-26.

Dobbin ZC, Katre AA, Ziebarth A, Shah M, Steg AD, Alvarez RD, Conner MG, Landen CN (2012) Use of an optimized primary ovarian cancer xenograft model to mimic patient tumor biology and heterogeneity. ASCO Meet Abstr 30(15_suppl): 5036.

Engelman JA (2009) Targeting PI3K signalling in cancer: opportunities, challenges and limitations. Nat Rev Cancer 9(8): 550-562.

Fujimoto H, Onishi N, Kato N, Takekawa M, Xu XZ, Kosugi A, Kondo T, Imamura M, Oishi I, Yoda A, Minami Y (2006) Regulation of the antioncogenic Chk2 kinase by the oncogenic Wip1 phosphatase. Cell Death Differ 13(7): 1170-1180.

Fujimura M, Katsumata N, Tsuda H, Uchi N, Miyazaki S, Hidaka T, Sakai M, Saito S (2002) HER2 is frequently over-expressed in ovarian clear cell adenocarcinoma: possible novel treatment modality using recombinant monoclonal antibody against HER2, trastuzumab. Jpn J Cancer Res 93(11): $1250-1257$.

Gandhi L, Camidge DR, Ribeiro de Oliveira M, Bonomi P, Gandara D, Khaira D, Hann CL, McKeegan EM, Litvinovich E, Hemken PM, Dive C, Enschede SH, Nolan C, Chiu YL, Busman T, Xiong H, Krivoshik AP, Humerickhouse R, Shapiro GI, Rudin CM (2011) Phase I study of Navitoclax (ABT-263), a novel Bcl-2 family inhibitor, in patients with small-cell lung cancer and other solid tumors. J Clin Oncol 29(7): 909-916.

Gao X, Tate P, Hu P, Tjian R, Skarnes WC, Wang Z (2008) ES cell pluripotency and germ-layer formation require the SWI/SNF chromatin remodeling component BAF250a. Proc Natl Acad Sci USA 105(18): 6656-6661.

Gross AL, Kurman RJ, Vang R, Shih IeM, Visvanathan K (2010) Precursor lesions of high-grade serous ovarian carcinoma: morphological and molecular characteristics. J Oncol 2010: 126295. 
Guan B, Wang TL, Shih IM (2011) ARID1A, a factor that promotes formation of SWI/SNF-mediated chromatin remodeling, is a tumor suppressor in gynecologic cancers. Cancer Res 71: 6718-6727.

Gui Y, Guo G, Huang Y, Hu X, Tang A, Gao S, Wu R, Chen C, Li X, Zhou L, He M, Li Z, Sun X, Jia W, Chen J, Yang S, Zhou F, Zhao X, Wan S, Ye R, Liang C, Liu Z, Huang P, Liu C, Jiang H, Wang Y, Zheng H, Sun L, Liu X, Jiang Z, Feng D, Chen J, Wu S, Zou J, Zhang Z, Yang R, Zhao J, Xu C, Yin W, Guan Z, Ye J, Zhang H, Li J, Kristiansen K, Nickerson ML, Theodorescu D, Li Y, Zhang X, Li S, Wang J, Yang H, Wang J, Cai Z (2011) Frequent mutations of chromatin remodeling genes in transitional cell carcinoma of the bladder. Nat Genet 43(9): 875-878.

Hashiguchi Y, Tsuda H, Inoue T, Berkowitz RS, Mok SC (2006) PTEN expression in clear cell adenocarcinoma of the ovary. Gynecol Oncol 101(1): 71-75.

Heitz F, Harter P, Barinoff J, Beutel B, Kannisto P, Grabowski JP, Heitz J, Kurzeder C, du Bois A (2012) Bevacizumab in the treatment of ovarian cancer. Adv Ther 29(9): 723-735.

Hetland TE, Hellesylt E, Flørenes VA, Tropé C, Davidson B, Kærn J (2011) Class III $\beta$-tubulin expression in advanced-stage serous ovarian carcinoma effusions is associated with poor survival and primary chemoresistance. Hum Pathol 42(7): 1019-1026.

Hirasawa A, Saito-Ohara F, Inoue J, Aoki D, Susumu N, Yokoyama T, Nozawa S, Inazawa J, Imoto I (2003) Association of 17q21-q24 gain in ovarian clear cell adenocarcinomas with poor prognosis and identification of PPM1D and APPBP2 as likely amplification targets. Clin Cancer Res 9(6): 1995-2004.

Itamochi H, Kigawa J, Terakawa N (2008) Mechanisms of chemoresistance and poor prognosis in ovarian clear cell carcinoma. Cancer Sci 99(4): 653-658.

Jenison EL, Montag AG, Griffiths CT, Welch WR, Lavin PT, Greer J, Knapp RC (1989) Clear cell adenocarcinoma of the ovary: a clinical analysis and comparison with serous carcinoma. Gynecol Oncol 32(1): 65-71.

Jones S, Wang TL, Shih IeM, Mao TL, Nakayama K, Roden R, Glas R, Slamon D, Diaz Jr LA, Vogelstein B, Kinzler KW, Velculescu VE, Papadopoulos N (2010) Frequent mutations of chromatin remodeling gene ARID1A in ovarian clear cell carcinoma. Science 330(6001): 228-231.

Katagiri A, Nakayama K, Rahman MT, Rahman M, Katagiri H, Nakayama N, Ishikawa M, Ishibashi T, Iida K, Kobayashi H, Otsuki Y, Nakayama S, Miyazaki K (2011) Loss of ARID1A expression is related to shorter progression-free survival and chemoresistance in ovarian clear cell carcinoma. Mod Pathol 25: 282-288.

Kato N, Sasou S, Motoyama T (2006) Expression of hepatocyte nuclear factor-1beta (HNF-1beta) in clear cell tumors and endometriosis of the ovary. Mod Pathol 19(1): 83-89.

Kennedy AW, Biscotti CV, Hart WR, Webster KD (1989) Ovarian clear cell adenocarcinoma. Gynecol Oncol 32(3): 342-349.

Ketabi Z, Bartuma K, Bernstein I, Malander S, Gronberg H, Bjorck E, Holck S, Nilbert M (2011) Ovarian cancer linked to Lynch syndrome typically presents as early-onset, non-serous epithelial tumors. Gynecol Oncol 121(3): $462-465$.

Khwaja A (1999) Akt is more than just a Bad kinase. Nature 401(6748): 33-34.

Kobel M, Kalloger SE, Carrick J, Huntsman D, Asad H, Oliva E, Ewanowich CA, Soslow RA, Gilks CB (2009) A limited panel of immunomarkers can reliably distinguish between clear cell and high-grade serous carcinoma of the ovary. Am J Surg Pathol 33(1): 14-21.

Köbel M, Kalloger SE, Santos JL, Huntsman DG, Gilks CB, Swenerton KD (2010) Tumor type and substage predict survival in stage I and II ovarian carcinoma: Insights and implications. Gynecol Oncol 116(1): 50-56.

Kuo KT, Mao TL, Jones S, Veras E, Ayhan A, Wang TL, Glas R, Slamon D, Velculescu VE, Kuman RJ, Shih IeM (2009) Frequent activating mutations of PIK3CA in ovarian clear cell carcinoma. Am J Pathol 174(5): 1597-1601.

Kurman RJ, Shih IeM (2010) The origin and pathogenesis of epithelial ovarian cancer: a proposed unifying theory. Am J Surg Pathol 34(3): 433-443.

Lee Y, Miron A, Drapkin R, Nucci MR, Medeiros F, Saleemuddin A, Garber J, Birch C, Mou H, Gordon RW, Cramer DW, McKeon FD, Crum CP (2007) A candidate precursor to serous carcinoma that originates in the distal fallopian tube. J Pathol 211(1): 26-35.

Lu X, Nguyen TA, Moon SH, Darlington Y, Sommer M, Donehower LA (2008) The type 2C phosphatase Wip1: an oncogenic regulator of tumor suppressor and DNA damage response pathways. Cancer Metastasis Rev 27(2): 123-135.
Mabuchi S, Kawase C, Altomare DA, Morishige K, Hayashi M, Sawada K, Ito K, Terai Y, Nishio Y, Klein-Szanto AJ, Burger RA, Ohmichi M, Testa JR, Kimura T (2010) Vascular endothelial growth factor is a promising therapeutic target for the treatment of clear cell carcinoma of the ovary. Mol Cancer Ther 9(8): 2411-2422.

Mabuchi S, Kawase C, Altomare DA, Morishige K, Sawada K, Hayashi M, Tsujimoto M, Yamoto M, Klein-Szanto AJ, Schilder RJ, Ohmichi M, Testa JR, Kimura T (2009) mTOR is a promising therapeutic target both in cisplatin-sensitive and cisplatin-resistant clear cell carcinoma of the ovary. Clin Cancer Res 15(17): 5404-5413.

Mackay HJ, Brady MF, Oza AM, Reuss A, Pujade-Lauraine E, Swart AM, Siddiqui N, Colombo N, Bookman MA, Pfisterer J, du Bois A. Gynecologic Cancer InterGroup (2010) Prognostic relevance of uncommon ovarian histology in women with stage III/IV epithelial ovarian cancer. Int $J$ Gynecol Cancer 20(6): 945-952.

Mamo A, Cavallone L, Tuzmen S, Chabot C, Ferrario C, Hassan S, Edgren H, Kallioniemi O, Aleynikova O, Przybytkowski E, Malcolm K, Mousses S, Tonin PN, Basik M (2012) An integrated genomic approach identifies ARID1A as a candidate tumor-suppressor gene in breast cancer. Oncogene 31(16): 2090-2100.

Martin SA, McCarthy A, Barber LJ, Burgess DJ, Parry S, Lord CJ, Ashworth A (2009) Methotrexate induces oxidative DNA damage and is selectively lethal to tumour cells with defects in the DNA mismatch repair gene MSH2. EMBO Mol Med 1(6-7): 323-337.

McCluggage WG (2008) My approach to and thoughts on the typing of ovarian carcinomas. J Clin Pathol 61(2): 152-163.

Nagl Jr NG, Patsialou A, Haines DS, Dallas PB, Beck Jr GR, Moran E (2005) The p270 (ARID1A/SMARCF1) subunit of mammalian SWI/SNF-related complexes is essential for normal cell cycle arrest. Cancer Res 65(20): 9236-9244.

Neve RM, Chin K, Fridlyand J, Yeh J, Baehner FL, Fevr T, Clark L, Bayani N, Coppe JP, Tong F, Speed T, Spellman PT, DeVries S, Lapuk A, Wang NJ, Kuo WL, Stilwell JL, Pinkel D, Albertson DG, Waldman FM,

McCormick F, Dickson RB, Johnson MD, Lippman M, Ethier S, Gazdar A, Gray JW (2006) A collection of breast cancer cell lines for the study of functionally distinct cancer subtypes. Cancer Cell 10(6): 515-527.

Pal T, Permuth-Wey J, Kumar A, Sellers TA (2008) Systematic review and meta-analysis of ovarian cancers: estimation of microsatellite-high frequency and characterization of mismatch repair deficient tumor histology. Clin Cancer Res 14(21): 6847-6854.

Pather S, Quinn MA (2005) Clear-cell cancer of the ovary-is it chemosensitive? Int J Gynecol Cancer 15(3): 432-437.

Perrotti D, Neviani P (2008) Protein phosphatase 2A (PP2A), a drugable tumor suppressor in Ph1 (+) leukemias. Cancer Metastasis Rev 27(2): 159-168.

Rahman M, Nakayama K, Rahman MT, Nakayama N, Ishikawa M, Katagiri A, Iida K, Nakayama S, Otsuki Y, IeM Shih, Miyazaki K (2012) Clinicopathologic and biological analysis of PIK3CA mutation in ovarian clear cell carcinoma. Hum Pathol 43(12): 2197-2206.

Reisman D, Glaros S, Thompson EA (2009) The SWI/SNF complex and cancer. Oncogene 28(14): 1653-1668.

Schwartz DR, Kardia SL, Shedden KA, Kuick R, Michailidis G, Taylor JM, Misek DE, Wu R, Zhai Y, Darrah DM, Reed H, Ellenson LH, Giordano TJ, Fearon ER, Hanash SM, Cho KR (2002) Gene expression in ovarian cancer reflects both morphology and biological behavior, distinguishing clear cell from other poor-prognosis ovarian carcinomas. Cancer Res 62(16): 4722-4729.

Shain AH, Giacomini CP, Matsukuma K, Karikari CA, Bashyam MD, Hidalgo M, Maitra A, Pollack JR (2012) Convergent structural alterations define SWItch/Sucrose NonFermentable (SWI/SNF) chromatin remodeler as a central tumor suppressive complex in pancreatic cancer. Proc Natl Acad Sci USA 109(5): E252-E259.

Shaw TJ, Senterman MK, Dawson K, Crane CA, Vanderhyden BC (2004) Characterization of intraperitoneal, orthotopic, and metastatic xenograft models of human ovarian cancer. Mol Ther 10(6): 1032-1042.

Sheikh-Hamad D, Cacini W, Buckley AR, Isaac J, Truong LD, Tsao CC, Kishore BK (2004) Cellular and molecular studies on cisplatin-induced apoptotic cell death in rat kidney. Arch Toxicol 78(3): 147-155.

Shreeram S, Demidov ON, Hee WK, Yamaguchi H, Onishi N, Kek C, Timofeev ON, Dudgeon C, Fornace AJ, Anderson CW, Minami Y, Appella E, Bulavin DV (2006) Wip1 phosphatase modulates ATMdependent signaling pathways. Mol Cell 23(5): 757-764.

Siddiqui GK, Maclean AB, Elmasry K, Wong Te Fong A, Morris RW, Rashid M, Begent RH, Boxer GM (2011) Immunohistochemical 
expression of VEGF predicts response to platinum based chemotherapy in patients with epithelial ovarian cancer. Angiogenesis 14(2): 155-161.

Skirnisdottir I, Seidal T, Karlsson MG, Sorbe B (2005) Clinical and biological characteristics of clear cell carcinomas of the ovary in FIGO stages I-II. Int J Oncol 26(1): 177-183.

Spentzos D, Levine DA, Kolia S, Otu H, Boyd J, Libermann TA, Cannistra SA (2005) Unique gene expression profile based on pathologic response in epithelial ovarian cancer. J Clin Oncol 23(31): 7911-7918.

Stany MP, Vathipadiekal V, Ozbun L, Stone RL, Mok SC, Xue H, Kagami T, Wang Y, McAlpine JN, Bowtell D, Gout PW, Miller DM, Gilks CB, Huntsman DG, Ellard SL, Wang YZ, Vivas-Mejia P, Lopez-Berestein G, Sood AK, Birrer MJ (2011) Identification of novel therapeutic targets in microdissected clear cell ovarian cancers. PLoS One 6(7): e21121.

Suehiro Y, Sakamoto M, Umayahara K, Iwabuchi H, Sakamoto H, Tanaka N, Takeshima N, Yamauchi K, Hasumi K, Akiya T, Sakunaga H, Muroya T, Numa F, Kato H, Tenjin Y, Sugishita T (2000) Genetic aberrations detected by comparative genomic hybridization in ovarian clear cell adenocarcinomas. Oncology 59(1): 50-56.

Sugiyama T, Kamura T, Kigawa J, Terakawa N, Kikuchi Y, Kita T, Suzuki M, Sato I, Taguchi K (2000) Clinical characteristics of clear cell carcinoma of the ovary: a distinct histologic type with poor prognosis and resistance to platinum-based chemotherapy. Cancer 88(11): 2584-2589.

Takano M, Sugiyama T, Yaegashi N, Sakuma M, Suzuki M, Saga Y, Kuzuya K, Kigawa J, Shimada M, Tsuda H, Moriya T, Yoshizaki A, Kita T, Kikuchi Y (2008) Low response rate of second-line chemotherapy for recurrent or refractory clear cell carcinoma of the ovary: a retrospective Japan Clear Cell Carcinoma Study. Int J Gynecol Cancer 18(5): 937-942.

Takekawa M, Adachi M, Nakahata A, Nakayama I, Itoh F, Tsukuda H, Taya Y, Imai K (2000) p53-inducible wip1 phosphatase mediates a negative feedback regulation of p38 MAPK-p53 signaling in response to UV radiation. EMBO J 19(23): 6517-6526.

Tan DS, Iravani M, McCluggage WG, Lambros MB, Milanezi F, Mackay A, Gourley C, Geyer FC, Vatcheva R, Millar J, Thomas K, Natrajan R, Savage K, Fenwick K, Williams A, Jameson C, El-Bahrawy M, Gore ME, Gabra H, Kaye SB, Ashworth A, Reis-Filho JS (2011) Genomic analysis reveals the molecular heterogeneity of ovarian clear cell carcinomas. Clin Cancer Res 17(6): 1521-1534.

Tan DS, Kaye S (2007) Ovarian clear cell adenocarcinoma: a continuing enigma. J Clin Pathol 60(4): 355-360.

Tan DS, Lambros MB, Rayter S, Natrajan R, Vatcheva R, Gao Q, Marchiò C, Geyer FC, Savage K, Parry S, Fenwick K, Tamber N, Mackay A, Dexter T, Jameson C, McCluggage WG, Williams A, Graham A, Faratian D, ElBahrawy M, Paige AJ, Gabra H, Gore ME, Zvelebil M, Lord CJ, Kaye SB, Ashworth A, Reis-Filho JS (2009) PPM1D is a potential therapeutic target in ovarian clear cell carcinomas. Clin Cancer Res 15(7): 2269-2280.

Tentler JJ, Tan AC, Weekes CD, Jimeno A, Leong S, Pitts TM, Arcaroli JJ, Messersmith WA, Eckhardt SG (2012) Patient-derived tumour xenografts as models for oncology drug development. Nat Rev Clin Oncol 9(6): $338-350$.
Terasawa K, Sagae S, Toyota M, Tsukada K, Ogi K, Satoh A, Mita H, Imai K, Tokino T, Kudo R (2004) Epigenetic inactivation of TMS1/ASC in ovarian cancer. Clin Cancer Res 10(6): 2000-2006.

Wiegand KC, Shah SP, Al-Agha OM, Zhao Y, Tse K, Zeng T, Senz J, McConechy MK, Anglesio MS, Kalloger SE, Yang W, Heravi-Moussavi A, Giuliany R, Chow C, Fee J, Zayed A, Prentice L, Melnyk N, Turashvili G, Delaney AD, Madore J, Yip S, McPherson AW, Ha G, Bell L, Fereday S, Tam A, Galletta L, Tonin PN, Provencher D, Miller D, Jones SJ, Moore RA, Morin GB, Oloumi A, Boyd N, Aparicio SA, IeM Shih, Mes-Masson AM, Bowtell DD, Hirst M, Gilks B, Marra MA, Huntsman DG (2010) ARID1A mutations in endometriosis-associated ovarian carcinomas. N Engl J Med 363(16): 1532-1543.

Wilson BG, Roberts CW (2011) SWI/SNF nucleosome remodellers and cancer. Nat Rev Cancer 11(7): 481-492.

Wong M, Tan N, Zha J, Peale FV, Yue P, Fairbrother WJ, Belmont LD (2012) Navitoclax (ABT-263) reduces $\mathrm{Bcl}-\mathrm{x}(\mathrm{L})$-mediated chemoresistance in ovarian cancer models. Mol Cancer Ther 11(4): 1026-1035.

Yamaguchi K, Mandai M, Oura T, Matsumura N, Hamanishi J, Baba T, Matsui S, Murphy SK, Konishi I (2010) Identification of an ovarian clear cell carcinoma gene signature that reflects inherent disease biology and the carcinogenic processes. Oncogene 29(12): 1741-1752.

Yamaguchi K, Mandai M, Toyokuni S, Hamanishi J, Higuchi T, Takakura K, Fujii S (2008) Contents of endometriotic cysts, especially the high concentration of free iron, are a possible cause of carcinogenesis in the cysts through the iron-induced persistent oxidative stress. Clin Cancer Res 14(1): 32-40.

Yamamoto S, Tsuda H, Takano M, Iwaya K, Tamai S, Matsubara O (2011) PIK3CA mutation is an early event in the development of endometriosis-associated ovarian clear cell adenocarcinoma. J Pathol 225(2): 189-194.

Yap TA, Yan L, Patnaik A, Fearen I, Olmos D, Papadopoulos K, Baird RD, Delgado L, Taylor A, Lupinacci L, Riisnaes R, Pope LL, Heaton SP, Thomas G, Garrett MD, Sullivan DM, de Bono JS, Tolcher AWl (2011) First-in-man clinical trial of the oral pan-AKT inhibitor MK-2206 in patients with advanced solid tumors. J Clin Oncol 29(35): 4688-4695.

Yoshida H, Ishiko O, Sumi T, Matsumoto Y, Ogita S (2001) Survivin, bcl-2 and matrix metalloproteinase-2 enhance progression of clear cell- and serous-type ovarian carcinomas. Int J Oncol 19(3): 537-542.

Zorn KK, Bonome T, Gangi L, Chandramouli GV, Awtrey CS, Gardner GJ, Barrett JC, Boyd J, Birrer MJ (2005) Gene expression profiles of serous, endometrioid, and clear cell subtypes of ovarian and endometrial cancer. Clin Cancer Res 11(18): 6422-6430.

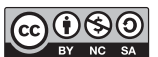

This work is licensed under the Creative Commons Attribution-NonCommercial-Share Alike 3.0 Unported License. To view a copy of this license, visit http://creativecommons. org/licenses/by-nc-sa/3.0/ 